is going to the famous Wu-tchi-shan or Five Fingers Mountain. As the mountain attains the height of more than 2,000 metres, zoological specimens, especially land vertebrates, will be thoroughly collected in order to study the problem of vertical distribution. Another party will make a coastal survey and pay more attention to the sea fauna.

\section{Research and Industry in New Zealand}

New Zealand's position in relation to world commerce was reviewed by the Governor-General, Lord Bledisloe, on September 29 in an address to the Canterbury Chamber of Commerce at Christchurch. In the course of the address he referred to the resentment often expressed in regard to excessive mechanisation and other social and economic ills entailed by the progress of scientific research and the application to industrial processes of the resulting discoveries. The remedy is to be sought, he suggested, not in arresting the march of science, especially in a country which has so much to gain from agricultural and other scientific research, but rather in redoubling research in those fields of economics, psychology, sociology and education in which are to be sought solutions of those problems, which have hitherto baffled mankind, of the distribution of the wealth which the applications of other branches of science have already made abundantly accessible. From the enunciation of this doctrine of the socio-centrality of present-day science, he passed on to consider the limits within and conditions on which State guidance and organisation are likely to produce better results than unshackled individual enterprise.

\section{"Discovery" Report on Foraminifera of South Georgia}

A correspondent, Mr. M. E. Challen, has directed our attention to the fact that in Mr. A. Earland's report on the Foraminifera of South Georgia (Discovery Reports, 7, 27-138 ; 1933), a new species (No. 158) Bigenerina minutissima is recorded from two stations, WS 199 , WS 472 , not included in the chart. Mr. Earland informs us that the species in question was not found in the South Georgia area, and that its inclusion was an error observed too late for correction in proof. The two stations, WS 199, WS 472, are in the deep water of the Scotia Sea, within the area covered by his forthcoming report on Antarctic Foraminifera. References to them have also crept into the South Georgia report under Ammobaculites agglutinans (No. 116), Ammomarginulina ensis (No. 122) and Clavulina communis (No. 165), but are of less importance as these species were found elsewhere in the South Georgia area. Protozoologists may be glad to rectify these errors in their copies of the report.

\section{Prof. S. H. Vines, F.R.S.}

OuR Oxford correspondent writes: "The tenure of the Sherardian professorship of botany by the late Sydney Howard Vines, F.R.S., which lasted from 1888 until 1919, was marked by a notable development in the activity and usefulness of the botanical department of the University. The studies of this department, associated in former years with the names of Morison, Sherard, Dillenius, Sibthorp and Daubeny, to which a quickening stimulus had already been applied by the vigorous personality of Sir Isaac Bayley Balfour, were by Prof. Vines advanced to a high degree of efficiency; and the results of the energy which he brought to bear on the duties of his office are still apparent in the flourishing condition of the department of which Prof. A. G. Tansley, F.R.S., is the present head. The memory of Vines will live in Oxford as that of one whose outstanding ability and social charm made a deep and enduring impression on all his contemporaries."

\section{Aberdeen Public Library}

Arrangements in connexion with the meetings of the British Association in Aberdeen in September are in an advanced state. It happens that the jubilee of Aberdeen Public Library-established 1884-occurs this year, and the Library Committee proposed to celebrate the anniversary by offering the hospitality of the Library to representative members of the British Association, mainly in the form of an evening reception in the Central Library. It happens, however, that no evening is available in the Association's programme. Accordingly, the celebration is to take the form of a luncheon in the Reference Department of the Central Library on Friday, September 7 .

\section{New Committee for Research in Mental Disorders}

THE Medical Research Council, in consultation with the Board of Control, has appointed a new committee to advise and assist in the promotion of research into mental disorders. The reconstituted committee will include representatives not only of psychiatry, medical psychology, and the study of mental deficiency, but also of neurology, physiology, biochemistry, pathology, and genetics. The chairman of the Committee will be Prof. E. D. Adrian, of the Medical Research Council, and the following will also serve : Sir C. Hubert Bond, Board of Control ; Dr. Bernard Hart, University College Hospital, London ; Prof. D. K. Henderson, Royal Edinburgh Hospital for Mental and Nervous Disorders ; Dr. T. A. Ross, Cassel Hospital, Penshurst ; Dr. E. O. Lewis, Board of Control; Dr. C. P. Symonds, Guy's Hospital, London; Dr. J. H. Quastel, Cardiff City Mental Hospital ; Dr. J. G. Greenfield, National Hospital for Nervous Diseases, London ; F. L. Golla, Maudsley Hospital, London; and Dr. L. S. Penrose, Royal Eastern Counties' Institution, Colchester. Sir David Munro, of the Council's staff, will act as secretary.

\section{Research Conference on Spectroscopy and its Applications}

ON account of the enthusiastic response to the Spectroscopy Conference held at the Massachusetts Institute of Technology last summer, which was attended by more than a hundred workers from America and abroad, it has been decided by the Institute to hold a second conference this year. A 
programme of papers and discussions is being prepared on the following topics, among others : absorption spectrophotometry (application to analysis of organic and inorganic substances and to the diagnosis and treatment of disease); analysis by the emission spectrum (determination of metallic and other atomic and molecular constituents of samples); biological and chemical effects of spectral radiation; spectroscopy of the ultra-violet and infra-red; analysis of spectra, and measurement of wave-length. It is anticipated that the earlier sessions of the week will be of especial interest to biologists, medical research workers, and chemists. The main emphasis will then shift to subjects of ehief interest to the industrialist and engineer, the geologist, and the metallurgist. The latter part of the week will be devoted to more theoretical problems of - the spectroscopist. The meetings will be open to anyone interested in the topics under discussion. The Massachusetts Institute also announces a special programme of summer courses on spectroscopy and its applications to be given during the six weeks preceding the conference, which will deal primarily with applications of spectroscopy to biology, chemistry, geology, metallurgy, and mineralogy. Inquiries regarding the Conference and courses should be, addressed to Prof. G. R. Harrison, Department of Physics, Massachusetts Institute of Technology, Cambridge, Massachusetts.

\section{Announcements}

The Garton Prize of $\$ 500$ and Gold Medal of the British Empire Cancer Campaign, offered this year for an essay on "The Biological Effects and Mode of Action of Radiations upon Malignant and other Cells", has been awarded to Dr. H. A. Colwell, of Middlesex Hospital, London. As one of the other essays was of high merit, the Grand Council of the Campaign has decided that a second award, of $£ 100$, should be made to its authors, Dr. F. G. Spear in association with Dr. R. G. Canti, Mr. L. G. Grimmett, Dr. B. Holmes, Miss S. F. Cox and Dr. W. H. Love.

The Hon. Olrver Stanley, M.P., Minister of Transport, will unveil a tablet erected at University College, London, by the executive committee of the Trevithick Centenary Commemoration, on April 23. The tablet commemorates Trevithick's locomotive experiments in 1808 .

Prow. E. K. Rideal, professor of colloid science in the University of Cambridge, will deliver the twentyfourth annual May Lecture of the Institute of Metals on May 9 at the house of the Institution of Mechanical Engineers, taking as his subject "Gases and Metal Surfaces",

The Annual Congress of the South-Eastern Union of Scientific Societies will be held at the University of Reading on July 11-14. Further information can be obtained from the Hon. General Secretary, Mr. Edward A. Martin, 14, High View Close, Norwood, London, S.E.19.
A Tour of Norway (Oslo and Bergen areas) has been arranged by the Geologists' Association to take place on August 2-14. Further information can be obtained from the Secretary, Mr. W. L. Turner, 18, Valley Road, Shortlands, Bromley, Kent.

ProF. F. A. E. Crew, director of the Institute of Animal Genetics, University of Edinburgh, has received the following telegram from Prof. N. I. Vavilov: "All Union Soviet Conference at the Academy of Science, Leningrad, on the Evolution of Domestic Animals express greatest regret on the death of Professor Cossar Ewart, pioneer of investigations on the origin of domestic animals. President of Conference, Vavilov."

A course of lectures on "Pathological Research in its Relation to Medicine" will be given in the lecture theatre of the Bacteriological Department of the Institute of Pathology and Research, St. Mary's Hospital, London, W.2, on Thursdays at 5 p.m. commencing on April 12. Sir Almroth Wright, principal of the Institute, is giving the opening lecture. The other lecturers will be Prof. A. Bethe, H. W. Bell Cairns, Sir Bernard Spilsbury, Prof. J. B. S. Haldane, Prof. J. C. Drummond, Prof. E. N. da C. Andrade, Dr. Leonard Colebrook.

A course of two lectures delivered by Dr. A. N. Whitehead before the University of Chicago last October will be published shortly by the Cambridge University Press under the title "Nature and Life". The book is an attempt in brief to unite the world of science with the worlds of religion, art, literature and morality, and to show that Nature itself has processes, goals, beauty and values.

Applicatrons are invited for the following appoint. ments, on or before the dates mentioned:-A head of the Textile Department at the Municipal Technical College, Halifax-The Principal (April 20). A chemist for the Aeronautical Inspection Directorate, Air Ministry, Test House, Kidbrooke, S.E.-The Secretary, S.2, Air Ministry, Kingsway, W.C.2 (April 21). Two economists for the Ministry of Agriculture and Fisheries-The Secretary, Ministry of Agriculture and Fisheries, 10, Whitehall Place, London, S.W.1 (April 23). An assistant lecturer in chemistry (subsidiary botany or pharmacognosy or pharmacy) at the Belfast Municipal College of Technology-The Principal (April 24). Two chemists (Class II), male, in the Department of War Department ChemistThe Under-Secretary of State, The War Office (C. 5), London, S.W.1 (April 28). An assistant lecturer in geography at the University of Manchester-The Registrar (April 30). Examiners in anatomy and physiology for the fellowship and in biology, anatomy, physiology, etc., for the Conjoint Board, at the Royal College of Surgeons of England-The Secretary (May 1). An assistant lecturer in dietetics and physiology at the King's College of Household and Social Science, Campden Hill Road, London, W.8The Secretary (May 5). 